\title{
SEED HARVESTING AT DIFFERENT MATURITY STAGES OF SILIQUA ON SEED QUALITY OF RAPESEED-MUSTARD VARIETIES
}

\author{
A.H.M.M.R. Talukder ${ }^{1 *}$, M. Biswas ${ }^{2}$, M.N.H. Miah ${ }^{3}$, M.A. Kashem ${ }^{4}$ and L. Nahar ${ }^{5}$ \\ ${ }^{1}$ Scientific Officer, Plant Physiology Division, BARI, Joydebpur, Gazipur, \\ ${ }^{2}$ Professor, Jashore University of Science \& Technology, Jashore-7408, \\ ${ }^{3}$ Professor, Dept. of Agronomy and Haor Agriculture, Sylhet Agricultural University, Sylhet-3100, \\ ${ }^{4}$ Professor, Dept. of Soil Science, Sylhet Agricultural University, Sylhet-3100, \\ ${ }^{5}$ Asstt. Professor, Dept. of Agricultural Botany, Sher-e-Bangla Agricultural University, Dhaka-1207. \\ *Corresponding E-mail: motiurbari@yahoo.com
}

(Received: 25 September 2019, Accepted: 28 November 2019)

Keywords: Moisture percentage, germination percentage, vigor index, rapeseed-mustard, speed of germination, seedling length

\begin{abstract}
A laboratory experiment with three replicates was conducted at Plant Physiology Division research laboratory of Bangladesh Agricultural Research Institute (BARI) during November, 2015 to observe the seed quality of rapeseed-mustard by harvesting at different maturity stages of siliqua. Seeds were collected from siliqua of different rapeseed-mustard varieties and harvesting was made at different maturity stages based on their external color i.e., Green, pale yellow, Golden yellow and full maturity stage of siliqua. After harvesting of siliqua as per external color seeds were dried naturally about 48 hours and were packed in polythene and stored at laboratory environment for next season uses. Under laboratory condition seeds were evaluated in terms of moisture and germination percentage, speed of germination, root and shoot length, vigor index etc. Moisture content was found significantly at elevated level in respect of mustard varieties of BARI Sarisha-14 $\left(\mathrm{V}_{2}\right)$, BARI Sarisha-6 $\left(\mathrm{V}_{3}\right)$ and Tori-7 $\left(\mathrm{V}_{4}\right)$. The variety Tori-7 and BARI Sarisha-14 showed the highest vigor index-II \& vigor index-I, respectively. Among the harvesting stages, most of the parameters showed the highest standards in seeds harvesting at full maturity of siliqua stage $\left(\mathrm{H}_{4}\right)$ followed by the golden yellow siliqua stage $\left(\mathrm{H}_{3}\right)$ and pale yellow siliqua stages seeds $\left(\mathrm{H}_{2}\right)$.Irrespective of rapeseed-mustard varieties seed collected from golden yellow and pale yellow siliqua stages could be stored up to twelve month for next season without significant loss in terms of germination percentage and vigor followed by full maturity stages of siliqua harvested seeds $\left(\mathrm{H}_{4}\right)$.
\end{abstract}

\section{Introduction}

Harvest stage is one of the most important factors that influence the seed quality (Emilly et al., 2016). Harvest stage also affects the performance of seeds during storage and field condition. For this reason seed production technology advises the seeds should be harvested as close as possible to physiological maturity. Harvesting of crop at right stage of maturity assume greater importance because stage of maturity greatly influence the seed yield and quality. Cost effective yield and quality of seed manipulates along with stage of maturity at harvest (Demir \& Balkaya, 2008). Earlier and later harvested seeds than physiological maturity seeds remain respectively immature and more likely to be deteriorating as they are 
Talukder et al.

subjected to adverse conditions, which reduces the seed quality (Marcos- Filho, 2005). Seed quality like viability and vigor are the features of seed that facilitate the emergence and establishment of normal seedlings under wide range environments (Khan et al., 2012). Seedling emergence and crop establishment are the seed germination and vigor which has an important influence on the establishment of plant population that affects crop yield (Hampton, 2002). Seed quality likes genetically and physically pure seed, vigor and viable seeds and seeds free from seed borne pathogen produce normal seedlings which are typically determined by means of laboratory tests (Perry, 1980). These seed quality may deteriorates during field weathering (higher temperature, relative air humidity and oxygen/carbon dioxide ratio during pre-harvest), lacking of identify the optimum harvesting time (early and/or later harvesting) and storage. Laboratory germination test is important issue to know the pre information about performance of seeds under field condition due to significant correlation coefficients between field emergence and standard laboratory germination tests. Laboratory testing of seed germination is to assess seed quality or viability and to predict performance of the seed and seedling in the field. Laboratory seed testing aid to obtained information about different quality attributes viz., purity, moisture percentage, germination, vigor and health.

Early harvesting stage prior to full maturity resulted poor quality on the account of seed immaturity. So, this research was carried out to investigate the seeds quality of rapeseed-mustard cultivars at different stages of development and maturity.

\section{Materials and Methods}

The laboratory experiment was conducted at Plant Physiology Division Laboratory under Bangladesh Agricultural Research Institute (BARI), Joydebpur, and Gazipur-

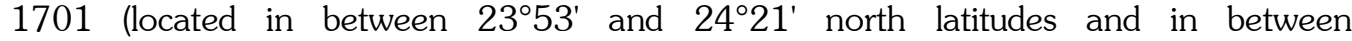
$90^{\circ} 09^{\prime}$ and $92^{\circ} 39^{\prime}$ east longitudes) during the period from 01 November to 07 November, 2015. Previously harvested of rapeseed-mustard seeds from four different maturity stages of siliqua were collected and these seeds were used as. $\mathrm{H}_{1}=$ Green siliqua stage harvested seed $\left(\mathrm{H}_{1}=\right.$ BARI Sarisha-11, BARI Sarisha14, BARI Sarisha-6 and Tori-7 were harvested at 88, 66, 81 and 65 days after sowing), $\mathrm{H}_{2}=$ pale yellow siliqua stage harvested seed $\left(\mathrm{H}_{2}=\right.$ BARI Sarisha- 11 , BARI Sarisha-14, BARI Sarisha-6 and Tori-7 were harvested at 98, 75, 90 and 74 days after sowing), $\mathrm{H}_{3}=$ Golden yellow siliqua stage harvested seed $\left(\mathrm{H}_{3}=\right.$ BARI Sarisha-11, BARI Sarisha-14, BARI Sarisha-6 and Tori-7 were harvested at 104, 85, 100 and 85 days after sowing) and $\mathrm{H}_{4}=$ Full maturity siliqua stage harvested seed $\left(\mathrm{H}_{4}=\right.$ BARI Sarisha-11, BARI Sarisha-14, BARI Sarisha-6 and Tori-7 were harvested at 109, 89, 103 and 89 days after sowing). The experiment was conducted in Completely Randomized Design (Factorial) with three replications.

The laboratory experiment was conducted just before observe the field performances of different harvesting stages seeds. Before initiate the laboratory experiment, collected seeds according to the treatment were preserved under freezing condition at $0{ }^{\circ} \mathrm{F}\left(-18{ }^{\circ} \mathrm{C}\right)$ or lower temperature. Twenty five seeds were picked up randomly from the each well-mixed seed lot. Enough care was taken for seed selection so that there is no causing biasness of results. Total forty eight Petri dishes were kept in a well-ventilated room at room temperature $\left({ }^{\circ} \mathrm{C}\right)$ for certain period (07 days). Then, filter paper was placed in the Petridis and moistened by drops of water from a wash bottle before seed placement. Twenty five seeds according to treatments were placed in the Petri dishes and everyday counted the germinated seeds on the basis root and shoot appearance. 


\section{Moisture percentage}

According to ISTA (1976) the moisture content of seed sample was determined. A blank moisture cup along with its cover was weighed and then twenty gram of each seed sample of rapeseed-mustard variety was taken into moisture cup and put into a pre-heated oven at temperature of $130 \cdot 2^{\circ} \mathrm{C}$ for one hour (Morshedet al.,2003). Then the weight of the container with its cover and contents were taken. The seed samples were cooled and weighed to work out the percent moisture content of the grains by using following formula (Khatunet al., 2009).

$$
\frac{\mathrm{M} 2-\mathrm{M} 3}{\mathrm{M} 2-\mathrm{M} 1} \times 100
$$

Where, $\mathrm{M}_{1}$ is the weight in ( $\mathrm{g}$ ) of the container and its cover, $\mathrm{M}_{2}$ is the weight in (g) of the container and its cover along with contents (seed) before drying and $\mathrm{M}_{3}$ is the weight in (g) of the container and its cover along with contents (seed) after drying.

\section{Germination percentage}

According to ISTA (1976) germination percentages were carried out. Twenty five seeds were collected from each seed lot according to treatment and put them on blotting paper into the Petri dishes at room temperature. After a week normal (well developed primary root system, intact hypocotyls without damage, an intact plumule a well-developed green leaf), abnormal (damaged, deformed and diseased seedlings) were counted. Germination percentage was counted by using following formula

$$
\text { Germination }(\%)=\frac{\text { Number of seeds germinated }}{\text { Number of seeds sown }} \times 100
$$

Root, shoot length $(\mathrm{cm})$ and dry weight of seedling ${ }^{-1}(\mathrm{~g})$

After a week 10 seedlings were randomly selected for study on the characters. The seedlings were divided into root and shoot and their lengths were measured in centimeter. The sum of root and shoot length was considered as seedling length. After measuring the root and shoot length stated above, root and shoot were put into paper packet separately, and placed them into pre-heated oven at $70^{\circ}{ }^{\circ} \mathrm{C}$ for 48 hours (Agrawal, 1986) to obtain seedlings ${ }^{-1}$ dry weight and expressed in gram (g).

\section{Speed of germination}

Speed of germination was calculated by using following formula (Sharma et al., 2013)

$$
\sum \mathrm{D} \times \frac{\mathrm{n}}{\mathrm{N}}
$$

Where, $\mathrm{n}$ is the number of germinated seeds at each day; $\mathrm{D}$ is the number of days after the start of the experiment, $\mathrm{N}$ is the total number of seeds.

\section{Seedling vigor index}

Seedling vigor index was calculated according to Reddy and Khan (2001) by using following formula

Vigor index- I = Percent of germination $\mathrm{Y}$ total dry weight of seedling

Vigor index- II $=$ Percent of germination 4 length of seedling 
Talukder et al.

The collected data on each treatment was statistically analyzed to obtain the level of significance using the computer based software MSTAT-C developed by Russel (1986). Mean differences among the treatments were tested with Least Significant Difference (LSD) test at 5\% level of significance.

\section{Results and Discussion}

\section{Effects of varieties}

Seed moisture content was observed among the rapeseed-mustard varieties significant (Table 1). Higher moisture content (6.67\%) was observed in var. BARI Sarisha-6 $\left(\mathrm{V}_{3}\right)$ that was statistically similar with the var. BARI Sarisha-14 $\left(\mathrm{V}_{2}\right)$ and Tori-7 $\left(\mathrm{V}_{4}\right)(6.63$ and $6.30 \%$, respectively). It might be due to the bolder seed size. The lowest moisture content $(5.61 \%)$ was observed in var. BARI Sarisha-11 $\left(V_{1}\right)$. The tested rapeseed-mustard varieties did not differ significantly in terms of germination percentage (Table 1). . The variety Tori-7 produced significantly the longest root $(5.44 \mathrm{~cm})$ than other varieties while BARI Sarisha-14 produced the shortest root $(3.52 \mathrm{~cm})$. Shoot length $(\mathrm{cm})$ differed significantly among the different varieties where BARI Sarisha-11 produced the maximum shoot $(3.61 \mathrm{~cm})$ that was statistically similar to BARI Sarisha-14 and Tori-7. The variety BARI Sarisha- 6 produced the shortest shoot length. Significant variations were observed in terms of seedling length among the rapeseed-mustard varieties and the longest seedling $(8.91 \mathrm{~cm})$ was noted in variety Tori-7 This variety also contributed longer root and shoot length (Table 1). Similarly, Mahesha et al. (2001b) also reported that varieties differed significantly in respect of seedling length harvested at different maturity dates. Significant differences in terms dry weight of seedling ${ }^{-1}$ among oilseed rape cultivars can be attributed to variation in genetic constitution, which may strongly influence seed vigor (Ghassemi - Golezani et al., 2010). Significantly among the different varieties the variety BARI Sarisha-14 $\left(\mathrm{V}_{2}\right)$ produced the highest dry weight of seedling ${ }^{-1}$ while other three varieties produced significantly lower and statistically similar. Variety had no significant effect for speed of germination and ranged from 25.6 to $25.7 \%$. The maximum vigor index-I (2.08) was produced by BARI Sarisha-14 which was statistically superior to other varieties. This might be due to the higher germination percentage and dry weight of seedling ${ }^{-1}$. The variety Tori-7 $\left(\mathrm{V}_{4}\right)$ produced significantly the highest vigor index-II (854.2) while BARI Sarisha-14 had the lowest vigor index-II and it was statistically at par with BARI Sarisha-6 (Table 1).

Table 1. Seed quality parameters of rapeseed-mustard varieties irrespective of seeds harvested at different stages of siliqua maturity

\begin{tabular}{|c|l|l|l|l|l|l|l|l|l|}
\hline Varieties & $\begin{array}{l}\text { Moisture } \\
(\%)\end{array}$ & $\begin{array}{l}\text { Germin } \\
\text {-ation } \\
(\%)\end{array}$ & $\begin{array}{l}\text { Root } \\
\text { length } \\
(\mathrm{cm})\end{array}$ & $\begin{array}{l}\text { Shoot } \\
\text { length } \\
(\mathrm{cm})\end{array}$ & $\begin{array}{l}\text { Seedling } \\
\text { length } \\
(\mathrm{cm})\end{array}$ & $\begin{array}{l}\text { Dry } \\
\text { weight } \\
\text { seedling-1 } \\
(\mathrm{g})\end{array}$ & $\begin{array}{l}\text { Germinati } \\
\text { on speed } \\
(\%)\end{array}$ & $\begin{array}{l}\text { Vigor } \\
\text { index-I }\end{array}$ & $\begin{array}{l}\text { Vigor } \\
\text { index-II }\end{array}$ \\
\hline $\mathrm{V}_{1}$ & $5.61 \mathrm{~b}$ & 96.0 & $\begin{array}{l}4.65 \\
\mathrm{~b}\end{array}$ & $3.61 \mathrm{a}$ & $8.30 \mathrm{~b}$ & $0.019 \mathrm{~b}$ & 25.7 & $\begin{array}{l}1.83 \\
\mathrm{~b}\end{array}$ & $\begin{array}{l}791.6 \\
\mathrm{~b}\end{array}$ \\
\hline $\mathrm{V}_{2}$ & $6.63 \mathrm{a}$ & 95.0 & $\begin{array}{l}3.52 \\
\mathrm{~d}\end{array}$ & $3.51 \mathrm{a}$ & $7.03 \mathrm{c}$ & $0.022 \mathrm{a}$ & 25.6 & $\begin{array}{l}2.08 \\
\mathrm{a}\end{array}$ & $669.1 \mathrm{c}$ \\
\hline $\mathrm{V}_{3}$ & $6.67 \mathrm{a}$ & 96.0 & $\begin{array}{l}4.10 \\
\mathrm{c}\end{array}$ & $3.24 \mathrm{~b}$ & $7.30 \mathrm{c}$ & $0.017 \mathrm{~b}$ & 25.7 & $\begin{array}{l}1.67 \\
\mathrm{~b}\end{array}$ & $702.8 \mathrm{c}$ \\
\hline $\mathrm{V}_{4}$ & $6.30 \mathrm{a}$ & 95.0 & $\begin{array}{l}5.44 \\
\mathrm{a}\end{array}$ & $3.46 \mathrm{a}$ & $8.91 \mathrm{a}$ & $0.017 \mathrm{~b}$ & 25.7 & $\begin{array}{l}1.67 \\
\mathrm{~b}\end{array}$ & $\begin{array}{l}854.2 \\
\mathrm{a}\end{array}$ \\
\hline $\mathrm{LSD}_{0.05}$ & 0.63 & $\mathrm{NS}$ & 0.28 & 0.17 & 0.32 & 0.0022 & $\mathrm{NS}$ & 0.18 & 40.2 \\
\hline $\mathrm{CV}_{(\%)}$ & 12.1 & 4.42 & 7.53 & 6.10 & 4.86 & 14.2 & 4.20 & 12.3 & 6.41 \\
\hline
\end{tabular}




\section{Seed Harvesting of Mustard}

123

Note: $\mathrm{V}_{1}=$ BARI Sarisha- $11 ; \mathrm{V}_{2}=$ BARI Sarisha- $14 ; \mathrm{V}_{3}=$ BARI Sarisha- $6 ; \mathrm{V}_{4}=$ Tori- 7

\section{Effects of seeds at different harvesting stages of siliqua maturity}

Seeds of different harvesting stages of siliqua maturity showed significant effect on moisture percentage. The moisture contents of the seed decreased with delay in the date of harvesting. Seeds collected from green siliqua harvesting stage $\left(\mathrm{H}_{1}\right)$ showed significantly the highest moisture percentage (7.20\%) and the lowest moisture percentage $(5.82 \%)$ was observed with the seeds that were collected from full maturity siliquae $\left(\mathrm{H}_{4}\right)$ stage which was at par with pale yellow $\left(\mathrm{H}_{2}\right)$ and golden yellow siliquae $\left(\mathrm{H}_{3}\right)$ stages (Table 2). Declining in moisture content and increasing seed mass resulted from delayed harvesting beyond physiological maturity. Germination percentage varied from 87 to $99 \%$ among different harvesting stages seeds. The highest germination percentages were 96 and $99 \%$ where seed contained $6.22,5.99$ and $5.82 \%$ moisture at pale yellow golden yellow and full maturity siliqua harvesting stages, respectively. In case of early harvesting stage $\left(\mathrm{H}_{1}\right)$ the germination was decreased to $87 \%$ and seed contained highest moisture (7.20\%). Lower germination (\%) in early harvested seeds may also be due to presence of more number of immature and unfilled seeds. But, Hay and White house (2017) stated that high quality seeds can recommend if the germination percentage observed at $85 \%$ at various maturity stages.

The root length was gradually increased onwards the maturity stages of seeds. The highest root length $(4.87 \mathrm{~cm})$ was recorded from the seeds harvested at full maturity siliqua stage. Seeds harvested at pale yellow and golden yellow siliquae stages produced significantly different and average root length was $4.55 \mathrm{~cm}$ and $4.51 \mathrm{~cm}$, respectively. The lowest root length $(3.74 \mathrm{~cm})$ was found in green siliqua harvesting stage. Similarly, El-abady (2015) also stated that the lowest root length was obtained from small seed. Shoot length did not differ significantly due to seeds harvested at different maturity stages of siliqua. It ranged from $3.42 \mathrm{~cm}$ to $3.53 \mathrm{~cm}$. The full maturity suliqua $\left(\mathrm{H}_{4}\right)$ stage produced the maximum seedling $(8.30 \mathrm{~cm})$ that was statistically similar with that of golden yellow siliqua $\left(\mathrm{H}_{3}\right)$ stage of maturity. The green siliqua $\left(\mathrm{H}_{1}\right)$ stage of maturity produced the shortest seedling length $(7.20 \mathrm{~cm})$. The highest seedling length was recorded in later harvesting stage, which might have been resulted from higher germination percentage and vigorous growth. Mahesha et al. (2001b) stated that seedling length was the highest in seeds collected at 35 days after flowering and the lowest in 30 days after flowering in sunflower. The seeds of full maturity of siliqua harvesting stage were the best in terms of seedling dry weight $(0.022 \mathrm{~g}$ seedling ${ }^{-1}$ ) that was statistically similar with seeds of golden yellow siliqua harvesting stage). Early harvesting stage gave the lowest dry weight seedling ${ }^{-1}$ $(0.015 \mathrm{~g})$. Khatun et al. (2010) stated that due to restricted supply of nutrient from mother plant, disruption of vascular connection, utilization of various physiological and metabolic process dry weights decreased. The seeds of pale yellow $\left(\mathrm{H}_{2}\right)$, golden yellow $\left(\mathrm{H}_{3}\right)$ and full maturity siliqua $\left(\mathrm{H}_{4}\right)$ stages had statistically higher speed of germination (Table 2). Shete et al. (1992) reported increase in germination with advancement of harvesting date. Seeds of green siliqua $\left(\mathrm{H}_{1}\right)$ stage had the lowest germination speed (23.5). According to Abdul-Baki and Anderson (1973) stated that seed lot showing a higher vigor index is considered to be more vigorous. Higher vigor index-I (2.20) was found with full maturity of siliqua $\left(\mathrm{H}_{4}\right)$ harvesting stage, which was similar to $\mathrm{H}_{3}$. The lowest vigor index-I (1.30) was observed in green siliqua harvesting $\left(\mathrm{H}_{1}\right)$ stage. Harvesting the seed before the attainment of physiological maturity recorded lesser viability and vigor potentials due to more number of immature seeds with high moisture content as reported in pea by Matthew (1973). Harvesting stage of $\mathrm{H}_{4}$ markedly increased 
Talukder et al.

vigor index-II. Seeds harvested at the stage of full maturity of siliqua $\left(\mathrm{H}_{4}\right)$ showed appreciably higher seed vigor index-Il probably due to associative effect of germination percentage and seedling length. Increased seed vigor index-II might be due to the maturation of seeds of later harvesting stages resulting improved germination percentage and seedling length (Gore et al., 1997).

\section{Interaction effects of varieties and seeds of different harvesting stages of siliquae maturity}

The interaction between varieties and seeds from different harvesting stages did not produce significant effect on moisture content of seed (Table 3). Moisture content ranged from 5.30 to $8.57 \%$. The germination percentage did not differ significantly due to interaction effects of varieties and harvesting stages seeds (Table 3). The interaction of harvesting stages seeds and the varieties showed a significant effect on root length (Table 3). In variety Tori-7 $\left(\mathrm{V}_{4}\right)$, with seeds of full maturity siliqua harvesting stage $\left(\mathrm{H}_{4}\right)$ resulted the highest root length $(6.48$ $\mathrm{cm})$. Interaction effects of the variety BARI Sarisha-14 $\left(\mathrm{V}_{2}\right)$ with seeds of golden yellow siliqua stage $\left(\mathrm{H}_{3}\right)\left(\mathrm{V}_{2} \mathrm{H}_{3}\right)$ was recorded the lowest root length $(3.34 \mathrm{~cm})$.

Table 2. Effects of seeds harvested at different stages of siliqua maturity on seed quality parameters of rapeseed-mustard irrespective of varieties

\begin{tabular}{|c|l|l|l|l|l|l|l|l|l|}
\hline $\begin{array}{l}\text { Harvesting } \\
\text { stages }\end{array}$ & $\begin{array}{l}\text { Moisture } \\
(\%)\end{array}$ & $\begin{array}{l}\text { Germi- } \\
\text { nation } \\
(\%)\end{array}$ & $\begin{array}{l}\text { Root } \\
\text { length } \\
(\mathrm{cm})\end{array}$ & $\begin{array}{l}\text { Shoot } \\
\text { length } \\
(\mathrm{cm})\end{array}$ & $\begin{array}{l}\text { Seedling } \\
\text { length } \\
(\mathrm{cm})\end{array}$ & $\begin{array}{l}\text { Dry } \\
\text { weight } \\
\text { seedling } \\
(\mathrm{g})\end{array}$ & $\begin{array}{l}\text { Germi- } \\
\text { nation } \\
\text { speed (\%) }\end{array}$ & $\begin{array}{l}\text { Vigor } \\
\text { index-I }\end{array}$ & $\begin{array}{l}\text { Vigor } \\
\text { index-II }\end{array}$ \\
\hline $\mathrm{H}_{1}$ & $7.20 \mathrm{a}$ & $\begin{array}{l}87.0 \\
\mathrm{~b}\end{array}$ & $\begin{array}{l}3.74 \\
\mathrm{c}\end{array}$ & 3.45 & $7.20 \mathrm{c}$ & $0.015 \mathrm{c}$ & $23.5 \mathrm{~b}$ & $\begin{array}{l}1.30 \\
\mathrm{c}\end{array}$ & $628.3 \mathrm{c}$ \\
\hline $\mathrm{H}_{2}$ & $6.22 \mathrm{~b}$ & $\begin{array}{l}96.0 \\
\mathrm{a}\end{array}$ & $\begin{array}{l}4.55 \\
\mathrm{~b}\end{array}$ & 3.42 & $7.97 \mathrm{~b}$ & $0.017 \mathrm{~b}$ & $25.9 \mathrm{a}$ & $\begin{array}{l}1.70 \\
\mathrm{~b}\end{array}$ & $767.7 \mathrm{~b}$ \\
\hline $\mathrm{H}_{3}$ & $5.99 \mathrm{~b}$ & $\begin{array}{l}99.0 \\
\mathrm{a}\end{array}$ & $\begin{array}{l}4.51 \\
\mathrm{~b}\end{array}$ & 3.53 & $8.04 \mathrm{ab}$ & $0.021 \mathrm{a}$ & $26.6 \mathrm{a}$ & $\begin{array}{l}2.11 \\
\mathrm{a}\end{array}$ & $\begin{array}{l}798.3 \\
\mathrm{ab}\end{array}$ \\
\hline $\mathrm{H}_{4}$ & $5.82 \mathrm{~b}$ & $\begin{array}{l}99.0 \\
\mathrm{a}\end{array}$ & $\begin{array}{l}4.87 \\
\mathrm{a}\end{array}$ & 3.43 & $8.30 \mathrm{a}$ & $0.022 \mathrm{a}$ & $26.6 \mathrm{a}$ & $\begin{array}{l}2.20 \\
\mathrm{a}\end{array}$ & $823.4 \mathrm{a}$ \\
\hline $\mathrm{LSD}(0.05)$ & 0.63 & 3.59 & 0.28 & - & 0.32 & 0.0044 & 0.88 & 0.18 & 40.2 \\
\hline $\mathrm{CV}(\%)$ & 12.1 & 4.52 & 7.53 & 6.07 & 4.86 & 14.2 & 4.16 & 12.3 & 6.41 \\
\hline
\end{tabular}

Note: $\mathrm{H}_{1}=$ Green siliqua stage harvested seed; $\mathrm{H}_{2}=$ Pale yellow siliqua stage harvested seed; $\mathrm{H}_{3}=$ Golden yellow siliqua stage harvested seeds; $\mathrm{H}_{4}=$ Full maturity siliqua stage harvested seeds

Interaction effects did not differ significantly in respect of shoot length. The effect of seeds harvested at different stages of siliqua maturity on seedling length of four rapeseed-mustard varieties was markedly influenced (Table 3).

The maximum seedling length was observed by the interactions of $\mathrm{V}_{4} \mathrm{H}_{4}, \mathrm{~V}_{4} \mathrm{H}_{3}$ and $\mathrm{V}_{4} \mathrm{H}_{2}$ while the minimum in $\mathrm{V}_{2} \mathrm{H}_{1}$. Vigor index-I did not differ significantly but all varieties responded significantly to harvesting stages of seeds, producing higher seed vigor index- II. The maximum seed vigor index- II (963.9) was recorded in the interaction of $\mathrm{V}_{4} \mathrm{H}_{4}$ that was statistically similar with interaction of $\mathrm{V}_{4} \mathrm{H}_{3}$ and $\mathrm{V}_{4} \mathrm{H}_{2}$. The lowest seed vigor index- II (551.6) was noted in the interaction of $\mathrm{V}_{2} \mathrm{H}_{1}$ (Table 3). 
Table 3. Interaction effects of varieties and seeds harvested at different stages of siliqua maturity on seed quality parameters of rapeseed-mustard under laboratory condition

\begin{tabular}{|c|c|c|c|c|c|c|c|c|c|}
\hline $\begin{array}{l}\text { Intera- } \\
\text { ction } \\
\text { (VH) }\end{array}$ & $\begin{array}{l}\text { Moisture } \\
\text { (\%) }\end{array}$ & $\begin{array}{l}\text { Germin- } \\
\text { ation } \\
(\%)\end{array}$ & $\begin{array}{l}\text { Root } \\
\text { length } \\
(\mathrm{cm})\end{array}$ & $\begin{array}{l}\text { Shoot } \\
\text { length } \\
(\mathrm{cm})\end{array}$ & $\begin{array}{l}\text { Seedling } \\
\text { length } \\
(\mathrm{cm})\end{array}$ & $\begin{array}{l}\text { Dry } \\
\text { weight } \\
\text { seedling }{ }^{-1} \\
\text { (g) }\end{array}$ & $\begin{array}{l}\text { Germi- } \\
\text { nation } \\
\text { speed (\%) }\end{array}$ & $\begin{array}{l}\text { Vigor } \\
\text { index-I }\end{array}$ & $\begin{array}{l}\text { Vigor } \\
\text { index-II }\end{array}$ \\
\hline $\mathrm{V}_{1} \mathrm{H}_{1}$ & 5.83 & 89.0 & $3.99 \mathrm{~d}-\mathrm{f}$ & 3.61 & $7.60 \mathrm{c}$ & 0.015 & 23.7 & 1.31 & 678.4 e-g \\
\hline $\mathrm{V}_{1} \mathrm{H}_{2}$ & 5.30 & 95.0 & $4.91 \mathrm{c}$ & 3.58 & $8.50 \mathrm{~b}$ & 0.018 & 25.4 & 1.65 & $804.3 \mathrm{~cd}$ \\
\hline $\mathrm{V}_{1} \mathrm{H}_{3}$ & 5.57 & 100.0 & $4.76 \mathrm{c}$ & 3.68 & $8.44 \mathrm{~b}$ & 0.023 & 26.8 & 2.33 & 844.0 bc \\
\hline $\mathrm{V}_{1} \mathrm{H}_{4}$ & 5.73 & 99.0 & $4.95 \mathrm{c}$ & 3.56 & $8.51 \mathrm{~b}$ & 0.021 & 26.5 & 2.04 & 839.7 bc \\
\hline $\mathrm{V}_{2} \mathrm{H}_{1}$ & 8.57 & 83.0 & $3.45 \mathrm{fg}$ & 3.24 & $6.70 \mathrm{e}$ & 0.017 & 22.1 & 1.40 & $551.6 \mathrm{~h}$ \\
\hline $\mathrm{V}_{2} \mathrm{H}_{2}$ & 6.30 & 97.0 & $3.36 \mathrm{~g}$ & 3.55 & $6.91 \mathrm{de}$ & 0.021 & 26.2 & 2.00 & $672.8 \mathrm{e}-\mathrm{g}$ \\
\hline $\mathrm{V}_{2} \mathrm{H}_{3}$ & 5.87 & 100.0 & $3.34 \mathrm{~g}$ & 3.68 & $\begin{array}{l}7.01 c^{-} \\
e\end{array}$ & 0.024 & 27.0 & 2.43 & 701.3 e-g \\
\hline $\mathrm{V}_{2} \mathrm{H}_{4}$ & 5.80 & 100.0 & $3.93 \mathrm{~d}-\mathrm{f}$ & 3.57 & $7.51 \mathrm{~cd}$ & 0.025 & 26.9 & 2.50 & $750.6 \mathrm{de}$ \\
\hline $\mathrm{V}_{3} \mathrm{H}_{1}$ & 7.10 & 91.0 & $3.93 \mathrm{~d}-\mathrm{f}$ & 3.28 & $\begin{array}{l}7.21 c^{-} \\
e\end{array}$ & 0.014 & 24.3 & 1.24 & $653.5 \mathrm{fg}$ \\
\hline $\mathrm{V}_{3} \mathrm{H}_{2}$ & 7.10 & 96.0 & $3.99 \mathrm{~d}-\mathrm{f}$ & 3.19 & $\begin{array}{l}7.20 \mathrm{c}^{-} \\
e^{-}\end{array}$ & 0.014 & 25.8 & 1.40 & $690.5 \mathrm{e}-\mathrm{g}$ \\
\hline $\mathrm{V}_{3} \mathrm{H}_{3}$ & 6.63 & 99.0 & $4.18 \mathrm{~d}$ & 3.20 & $7.40 \mathrm{~cd}$ & 0.019 & 26.3 & 1.84 & $728.0 \mathrm{~d}-\mathrm{f}$ \\
\hline $\mathrm{V}_{3} \mathrm{H}_{4}$ & 5.83 & 100.0 & $4.10 \mathrm{de}$ & 3.30 & $7.40 \mathrm{~cd}$ & 0.022 & 26.5 & 2.20 & $739.3 \mathrm{de}$ \\
\hline $\mathrm{V}_{4} \mathrm{H}_{1}$ & 7.23 & 87.0 & $\begin{array}{l}3.59 e^{-} \\
g\end{array}$ & 3.67 & $\begin{array}{l}7.30 \mathrm{c}^{-} \\
e\end{array}$ & 0.014 & 23.6 & 1.21 & $629.8 \mathrm{gh}$ \\
\hline $\mathrm{V}_{4} \mathrm{H}_{2}$ & 6.17 & 97.0 & $5.93 \mathrm{ab}$ & 3.34 & $9.30 \mathrm{a}$ & 0.016 & 26.1 & 1.60 & $903.1 \mathrm{ab}$ \\
\hline $\mathrm{V}_{4} \mathrm{H}_{3}$ & 5.90 & 99.0 & $5.77 \mathrm{~b}$ & 3.55 & $9.32 \mathrm{a}$ & 0.018 & 26.5 & 1.81 & $919.8 \mathrm{ab}$ \\
\hline $\mathrm{V}_{4} \mathrm{H}_{4}$ & 5.90 & 99.0 & $6.48 \mathrm{a}$ & 3.29 & $9.80 \mathrm{a}$ & 0.021 & 26.5 & 2.07 & $963.9 \mathrm{a}$ \\
\hline LSD $(0.05)$ & 1.26 & 7.18 & 0.055 & 0.35 & 0.64 & 0.002 & 1.78 & 0.37 & 80.4 \\
\hline CV (\%) & 12.1 & 4.52 & 7.53 & 6.07 & 4.86 & 14.2 & 4.16 & 12.3 & 6.41 \\
\hline
\end{tabular}

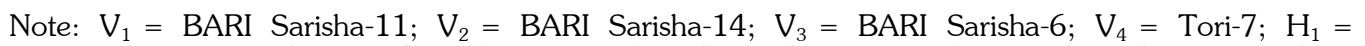

Green siliqua stage harvested seed; $\mathrm{H}_{2}=$ Pale yellow siliqua stage harvested seed; $\mathrm{H}_{3}=\mathrm{Golden}$ yellow siliqua stage harvested seed; $\mathrm{H}_{4}=$ Full maturity siliqua stage harvested seed 
Pearson's correlation matrix among different seed quality parameters of seeds harvested at different maturity stages of siliqua

Correlation matrix among the seed characters of rapeseed-mustard has been shown in Table 4. A positive and significant correlation was observed among root length, germination, germination speed, seedling length and vigor index- II; among germination, germination speed, dry matter weight, seedling length, vigor index- I, vigor index- II; among germination speed, dry matter weight of seedling, seedling length, vigor index- I and vigor index- II and among dry matter weight, vigor index-I and vigor index- II and between seedling length and vigor index- II and between vigor index-I and vigor index- II. Negative and non-significant correlation was found between root length and shoot length; among shoot length, germination, germination speed; between dry matter weight and moisture. A positive correlation $(r=0.596)$ between germination and dry matter was found by Mehta et al. (1993). Reddy and Khan (2001) found a positive and significant correlation $\left(0.68^{* *}\right)$ between germination and seedling dry weight, vigor index- I $\left(0.91^{* *}\right)$ and vigor index- II $\left(0.97^{* *}\right)$.

Table 4. Pearson's correlation matrix among different seed quality parameters of rapeseed-mustard

\begin{tabular}{|c|c|c|c|c|c|c|c|c|c|}
\hline & \multicolumn{9}{|c|}{ Correlation co-efficient ( $r$-value) } \\
\hline Character & $\begin{array}{l}\text { Root } \\
\text { length } \\
\text { (cm) }\end{array}$ & $\begin{array}{l}\text { Shoot } \\
\text { length } \\
\text { (cm) }\end{array}$ & $\begin{array}{l}\text { Germination } \\
(\%)\end{array}$ & $\begin{array}{l}\text { Germination } \\
\text { speed }\end{array}$ & $\begin{array}{l}\text { Dry } \\
\text { weight } \\
\text { seedling } \\
1 \quad(g)\end{array}$ & $\begin{array}{l}\text { Moisture } \\
\text { content }\end{array}$ & $\begin{array}{l}\text { Seedling } \\
\text { length }\end{array}$ & $\begin{array}{l}\text { Vigor } \\
\text { index-I }\end{array}$ & $\begin{array}{l}\text { Vigor } \\
\text { index-II }\end{array}$ \\
\hline Root length & 1.00 & $\begin{array}{l} \\
0.09^{\text {ns }}\end{array}$ & 0.32 & $0.32^{*}$ & $0.045^{3}$ & $-0.35^{\circ}$ & $0.97^{28}$ & $\underset{s}{0.083^{n}}$ & $0.91^{* *}$ \\
\hline $\begin{array}{l}\text { Shoot } \\
\text { length }\end{array}$ & & 1.00 & $-0.04^{\text {ns }}$ & $-.009^{\text {ns }}$ & $0.17^{\mathrm{ns}}$ & $-0.34^{*}$ & $0.16^{\mathrm{ns}}$ & $0.12^{\mathrm{ns}}$ & $0.10^{\mathrm{ns}}$ \\
\hline $\begin{array}{l}\text { Germinatio } \\
\mathrm{n}(\%)\end{array}$ & & & 1.00 & $0.98^{* *}$ & $0.57^{38}$ & $-0.34^{*}$ & $0.31^{*}$ & $0.63^{* *}$ & $0.64^{* *}$ \\
\hline $\begin{array}{l}\text { Germinatio } \\
\mathrm{n} \text { speed }\end{array}$ & & & & 1.00 & $0.56^{m}$ & $-0.37^{*}$ & $0.31^{*}$ & $0.62^{3 *}$ & $0.64^{* *}$ \\
\hline $\begin{array}{l}\text { Dry weight } \\
\text { seedling }{ }^{-1} \mathrm{~g}\end{array}$ & & & & & 1.00 & $-0.26^{\mathrm{ns}}$ & $0.09^{\text {ns }}$ & $0.97^{*}$ & $0.29^{*}$ \\
\hline $\begin{array}{l}\text { Moisture } \\
\text { content }\end{array}$ & & & & & & 1.00 & $-0.44^{2 *}$ & $-0.28^{*}$ & $-0.47^{* *}$ \\
\hline $\begin{array}{l}\text { Seedling } \\
\text { length }\end{array}$ & & & & & & & 1.00 & $0.11^{\mathrm{ns}}$ & $0.93^{* *}$ \\
\hline $\begin{array}{l}\text { Vigor } \\
\text { index-I }\end{array}$ & & & & & & & & 1.00 & $0.34^{*}$ \\
\hline $\begin{array}{l}\text { Vigor } \\
\text { index-II }\end{array}$ & & & & & & & & & 1.00 \\
\hline
\end{tabular}

\section{Conclusion}

Irrespective of rapeseed-mustard varieties seed collected from golden yellow stage of siliqua could be stored up to twelve month for next season without significant loss in terms of germination percentage and vigor followed by full maturity stages of siliqua harvested seeds $\left(\mathrm{H}_{4}\right)$. The results of this study could create the awareness among the rapeseed-mustard growers' to harvest the crop earlier such as pale yellow or golden yellow color stage of siliqua before attainment of full maturity considering the time saving.

\section{Acknowledgements}


We acknowledge the "Research and Research Infrastructure Development and Extension Project" funded by Government of the People's Republic of Bangladesh, Implemented by Bangladesh Agricultural Research Institute (BARI), Gazipur-1701, for providing fund to conduct the study. We also acknowledge the authority of the Plant physiology Division of BARI to conduct the research work providing adequate laboratory facilities.

\section{References}

Abdul-Baki, A.A., and J.D. Anderson. 1973. Physiological and biochemical deterioration of seed. In: Kozlowski, T.T. (2 ${ }^{\text {nd }}$ Eds.). Seed Biology. Academic Press, New York, London, pp.283-315.

Agrawal, P.K. 1986. Seed vigor concepts and measurements. In.Srivastava, J.P. and L.T. Simarsk (Eds.) Proceeding of the Seed production technology. ICARDA, Aleppo, Syria, pp.190-198.

AOSA. 2009. Seed Vigor Testing Handbook. Contribution No. 32 to the Handbook on Seed Testing.

Demir, I. and A. Balkaya. 2005. Seed development stages of Kale (Brassica oleracea var. acephala L.) genotypes in Turkey Hort. Sci. 32: 147-153.

Demir, I., A.M. Ashirov and K. Mavi. 2008. Effect of seed production environment and time of harvest on tomato (Lycopersicon esculentum) seedling growth. Res. J. Seed Sci. 1: 1-10.

El-abady, M.I. 2015. Influence of maize seed size/shape, planted at different depths and temperature on seed emergence and seedling vigor. Res. J. Seed Sci. 8(1): 1-11.

Emilly, R.A., M.S. De, S.D. Andrŭia, V.S. Tiago, G.R. Cleiton and T.R.A. Hugo. 2016. Different harvest times and physiological quality of coriander seeds. Rev. Bras. Eng. Agr. Amb. 20: 133-137.

Ghassemi-Golezani, K.S. Khomari, B. Dalil, A. HosseinzadehMahootchy and A. Chadordooz-Jeddi. 2010. Effects of seed aging on field performance of winter oilseed rape. J. Food Agric Environ. 8: 175-178.

Gore, S.V., R.B. Patil and G.R. Wankhade. 1997. Effect of maturity period and harvesting time on seed quality in soybean (Glycine max. [L.] Merill) cultivars. Seed Res. 25: 45-49.

Hampton, J.G. 2002. What is seed quality? Seed Sci.Tech. 30: 1-10.

Hay, F.R. and K.J. Whitehouse. 2017. Rethinking the approach to viability monitoring in seed gene banks. Conserv. Physiol. 5(1): 1-13.

ISTA. 1976. International rules for seed testing. Seed Sci. Tech. 4: 3-49.

Khan, N., R.H. Kazmi, L.A. Willems, A.W. Van Heusden, W. Ligterink and H.W Hilhorst. 2012. Exploring the natural variation for seedling traits and their link with seed dimensions in tomato. PLoS One,7(8): e43991.

Khatun, A., G. Kabir and M.A.H. Bhuiyan. 2009. Effect of harvesting stages on the seed quality of lentil (Lens culinaris L.) during storage. Bangladesh J. Agric. Res. 34: 565-576. 
Khanum et al.

Khatun, A., M.A.H. Bhuiyan, A. Nessa and S.B.M. Hossain. 2010. Effect of harvesting time on yield and yield attributed of Chickpea (Cicer arietinum L). Bangladesh J. Agric. Res. 35: 143-148.

Mahesha, C.R., A.S.I. Channaveeraswam, M.B. Kurdikeri, M. Shekhargouda and M.N. Merwade. 2001. Storability of sunflower seeds harvested at different maturity dates. Seed Res. 29(1): 98-102.

Marcos-filho, J. 1999. Strength tests: Importance and use. In: Krzyzanowski, F.C. R.D. Vieira and J.B. France Neto (Eds.) Seed vigor: concepts and tests. Londrina: Abrates, pp.1-21.

Matthew, S. 1973. The effect of time of harvest on the viability and preemergence mortality in soil of pea (Pisum sativum L.) seeds. Ann. Appl. Bio.73: 211-219.

Mehta, C.J., M.S. Kuhad, I.S. Sheoran and A.S. Nandwal. 1993. Studies on seed development and germination in chickpea cultivars. Seed Res. 21: 89-91.

Morshed, M.S., M. Begum, M.A. Bashar and W. Sultana. 2003. Effect of storage containers on seed quality of three pulses. Bangladesh $\mathrm{J}$. Life Earth Sci. 15: 107-112.

Nonogaki, H., G.W. Bassel and J.D. Bewley. 2010. Germination-Still a mystery. Plant Sci. 179: 574-581.

Perry, D.A. 1980. The concept of seed vigor and its relevance to seed production techniques. In: Hebblethwaite, P.D (ed) Seed Production. Proc. $28^{\text {th }}$ Easter School in Agric. Sci., Univ. Nottingham. Butterworths: London

Reddy, Y.T.N. and M.M. Khan. 2001. Effect of osmopriming on germination, seedling growth and vigor of Khirni (Mimusops hexandra) seeds. Seed Res. 29: 24-27.

Russell, D.F. 1986. MSTAT-C Package Programme.Crop and Soil Science Department, Michigan University, USA.

Sharma, P.V., Sardana and S.S. Kandhola. 2013. Effect of sowing dates and harvesting dates on germination and seedling vigor of Groundnut (Arachis hypogaea) cultivars. Res. J. Seed Sci. 6: 1-15.

Shete, D.M., A.R. Singh, A.P. Suryawanshi and V.S. Hudge. 1992. Seed germination and vigor at harvest in sunflower. Ann. Plant Phys. 6: 125132. 